\title{
Insulin influences the nitric oxide cyclic nucleotide pathway in cultured human smooth muscle cells from corpus cavernosum by rapidly activating a constitutive nitric oxide synthase
}

\author{
Giovanni Anfossi, Paola Massucco, Luigi Mattiello, Alessandra Balbo, Isabella Russo, Gabriella Doronzo, \\ Luigi Rolle ${ }^{2}$, Dario Ghigo ${ }^{1}$, Dario Fontana ${ }^{2}$, Amalia Bosia ${ }^{1}$ and Mariella Trovati \\ Diabetes Unit, Department of Clinical and Biological Sciences of the University of Turin, San Luigi Gonzaga Hospital, 10043 Orbassano, Turin, Italy, \\ ${ }^{1}$ Department of Genetics, Biology and Biochemistry of the University of Turin, Turin, Italy and ${ }^{2}$ Urology Unit, Department of Medical and Surgical \\ Sciences of the University of Turin, San Giovanni Battista Hospital, Turin, Italy
}

(Correspondence should be addressed to M Trovati; Email: mariella.trovati@unito.it)

\begin{abstract}
Aims: We have evaluated, in cultured human cavernosal smooth muscle cells, the expression and activity of calcium-dependent constitutive nitric oxide synthase (cNOS) and the ability of insulin to induce nitric oxide (NO) production and to increase intracellular cyclic nucleotides guanosine $3^{\prime}, 5^{\prime}$-cyclic monophosphate (cGMP) and adenosine $3^{\prime}, 5^{\prime}$-cyclic monophosphate (cAMP).

Methods: cNOS mRNA was detected by RT-PCR amplification, cNOS protein by immunofluorescence, cNOS activity as $\mathrm{L}-\left[{ }^{3} \mathrm{H}\right]$-citrulline production from $\mathrm{L}-\left[{ }^{3} \mathrm{H}\right]$-arginine and cyclic nucleotides by radioimmunoassay.

Results: cNOS mRNA and cNOS protein were found in cultured cells; cNOS activity was increased by 5-min exposure to $1 \mu \mathrm{mol} / \mathrm{l}$ calcium ionophore ionomycin (from $0.1094 \pm 0.0229$ to $0.2685 \pm$ $0.0560 \mathrm{pmol} / \mathrm{min}$ per $\mathrm{mg}$ cell protein, $P=0.011$ ) and to $2 \mathrm{nmol} / \mathrm{l}$ insulin (from $0.1214 \pm 0.0149$ to $0.2045 \pm 0.0290 \mathrm{pmol} / \mathrm{min}$ per $\mathrm{mg}$ cell protein, $P=0.041)$. Insulin increased both cGMP and cAMP in a dose- and time-dependent manner (i.e. with $2 \mathrm{nmol} / \mathrm{l}$ insulin, cGMP rose from $2.71 \pm$ 0.10 to $6.80 \pm 0.40 \mathrm{pmol} / 10^{6}$ cells at $30 \mathrm{~min}, P=0.0001$; cAMP from $1.26 \pm 0.06$ to $3.02 \pm$ $0.30 \mathrm{pmol} / 10^{6}$ cells at $\left.60 \mathrm{~min}, P=0.0001\right)$. NOS inhibitor $\mathrm{N}^{\mathrm{G}}$-monomethyl-L-arginine and phosphatidylinositol 3-kinase (PI 3-kinase) inhibitors wortmannin and LY 294002 blunted these effects of insulin. The action of insulin on cyclic nucleotides persisted in the presence of phosphodiesterase inhibition, guanylate cyclase activation by NO donors and adenylate cyclase activation by Iloprost or forskolin.

Conclusion: Human cavernosal smooth muscle cells, by expressing cNOS activity, are a source of NO and not only its target; in these cells, insulin rapidly activates cNOS through a PI 3-kinase pathway, with a consequent increase of both cyclic nucleotides, thus directly influencing the mechanisms involved in penile vascular tone and interplaying with classical haemodynamic mediators.
\end{abstract}

European Journal of Endocrinology 147 689-700

\section{Introduction}

Diabetes mellitus is a relevant cause of erectile dysfunction (1-3). The complex mechanism of erection implies: (i) increase of arterial inflow via cavernosal arteries, (ii) relaxation of corporal smooth muscle cells which opens corporal sinusoids and (iii) decrease of venous outflow with a consequent increase of intracorporal pressure $(4,5)$. Three separate components are involved in penile erection, namely: (i) central nervous system regulation, (ii) peripheral neurotransmission and (iii) haemodynamic response of the corporal bodies of the penis $(5-8)$. The last process is both endothelium mediated and under neurologic control, which involves cholinergic and nonadrenergicnoncholinergic neuroeffector systems $(5,7)$. As far as the neurological control is concerned, an essential role is played by the nonadrenergic-noncholinergic system and in particular by nitric oxide (NO), identified as a specific neurotransmitter $(7-13)$. Thus, both nerve fibres expressing NO synthase (NOS) and endothelial cells play a relevant role in the haemodynamic events of penile erection $(9,11,14-19)$. Effectors of the haemodynamic changes in septi and the arterial wall of corpus cavernosum are smooth muscle cells $(20,21)$ : they respond to vasorelaxant stimuli (such as NO, prostaglandins and vasoactive intestinal peptide), mainly through an increase of intracellular 
levels of cyclic nucleotides: guanosine $3^{\prime}, 5^{\prime}$-cyclic monophosphate (cGMP) and adenosine $3^{\prime}, 5^{\prime}$-cyclic monophosphate (cAMP) (9, 22). Cyclic nucleotides are responsible for smooth muscle relaxation mainly through a decreased cytosolic calcium $\left(\mathrm{Ca}^{2+}\right)$ availability (22-30). As far as the NO/cGMP pathway is concerned, it can be briefly summarized as follows: (i) smooth muscle cells from corpus cavernosum are targets of the NO released both by endothelial cells and nerve endings, (ii) in smooth muscle cells, NO activates soluble guanylate cyclase with a consequent synthesis of cGMP and (iii) cGMP reduces cytosolic $\mathrm{Ca}^{2+}$ content by inhibiting the inositol 1,4,5-trisphosphate-mediated $\mathrm{Ca}^{2+}$ release from intracellular stores $(25,27-32)$. Thus, biochemical pathways well known in the modulation of systemic arterial tone are operating in the cultured smooth muscle cells of corpus cavernosum $(26$, 28, 29).

In recent years, we have demonstrated the following. (i) Human arteriolar vascular smooth muscle cells express the constitutive, $\mathrm{Ca}^{2+} /$ calmodulin-dependent endothelial type constitutive NOS (cNOS), with a consequent basal production of NO (33). (ii) In these cells, insulin is able to stimulate cNOS, with a consequent increase of NO production and guanylate cyclase activation (33). (iii) Via this mechanism, insulin increases not only cGMP but also cAMP (33); this last phenomenon is not surprising, since NO donors, such as sodium nitroprusside (SNP) and glyceryl trinitrate (GTN), are able to increase both cGMP and cAMP in vascular smooth muscle cells (33) and in platelets $(34,35)$. It could be hypothesized that NO increases cGMP and that cGMP, by inhibiting a cAMP phosphodiesterase, increases cAMP concentrations (36); alternatively, it is possible that cAMP is produced by guanylate cyclase directly since this enzyme activity shows striking modifications when stimulated by NO, becoming able also to synthesize cAMP (37). (iv) Insulin increases - via NO - the effects on cAMP exerted by substances activating adenylate cyclase via receptordependent or receptor-independent mechanisms (33, 38,39 ). Thus, we have demonstrated that vascular smooth muscle cells are not only targets of the NO released by endothelial cells, but produce NO by themselves through a $\mathrm{Ca}^{2+}$-dependent NOS activity that insulin rapidly activates. The ability of insulin to activate cNOS has already been demonstrated by experiments in vivo $(40,41)$ and in vitro in other cell types: i.e. endothelial cells, where this effect of insulin is ascribed to the phosphatidylinositol 3-kinase (PI 3-kinase) pathway of insulin signalling (42), and in platelets (43).

Since smooth muscle cells from corpus cavernosum are a specialized type of vascular smooth muscle cells (20), we designed the present study in order to verify whether these cells are simple effectors of NO or play an active role in its production, as vascular smooth muscle cells. The presence of cNOS in these cells is a matter of recent debate $(44,45)$ and has never been shown by molecular biology techniques. Furthermore, the ability of these cells to produce NO in a constitutive way has never been studied and, therefore, the biological meaning of a putative cNOS activity in these cells is completely unknown.

In this study, we describe a technique to obtain primary cultures of smooth muscle cells from human corpus cavernosum (CSMC) and to characterize them from a biochemical point of view. The possibility of investigating the behaviour of this cell type in controlled conditions, such as in in vitro cultures, represents a relevant tool with which to investigate the mechanism of the physiological erectile response and the putative role of different mediators.

In particular, the present study aims to clarify the following in human CSMC: (i) the cell proliferation rate and dependence on growth factors and insulin; (ii) the expression of cNOS; (iii) the ability of ionomycin, a calcium ionophore, to induce production of NO, as biological proof of the presence of an active $\mathrm{Ca}^{2+}$ / calmodulin-dependent cNOS enzyme; (iv) the ability of insulin to rapidly activate cNOS and, consequently, to increase the production of NO; (v) the ability of insulin to increase, via NO, both cGMP and cAMP; (vi) the dependence of the putative effect exerted by insulin on the NO-cyclic nucleotide cascade on the PI 3-kinase pathway of insulin signalling; (vii) the ability of insulin to interplay with NO donors (GTN and SNP) as far as cyclic nucleotide levels are concerned; (viii) the ability of insulin to interplay with forskolin and the prostacyclin analogue Iloprost as far as cell cAMP levels are concerned.

\section{Materials and methods}

\section{Study design}

The study was carried out on CSMC of a 42-year-old otherwise healthy subject (without obesity, diabetes mellitus, arterial hypertension, dyslipidaemia or other known diseases), who underwent corporoplasty according to Nesbit for congenital penile curvature abnormality. Since corpus cavernosum biopsy is not part of the intervention, which relies on the reconstruction of tunica albuginea, the patient gave his informed consent according to the Helsinki Declaration of 1975, as revised in 1983, after being reassured that erectile tissue excision would be so small as to avoid any risk of impotence. Cells isolated from small pieces of about $1 \mathrm{~mm}^{2}$ gave six different proliferating foci, which were cultured and characterized according to the techniques described below. In these cells, we aimed to evaluate: (i) the proliferating features, according to standardized procedures; (ii) the presence of endothelial type cNOS mRNA by RT-PCR; (iii) the presence of cNOS protein by immunofluorescence; (iv) the functional activity of cNOS, which is a $\mathrm{Ca}^{2+}$-dependent enzyme, by measuring 
NO synthesis as L- $\left[{ }^{3} \mathrm{H}\right]$-citrulline synthesis from L$\left.{ }^{3} \mathrm{H}\right]$-arginine in cells exposed for $5 \mathrm{~min}$ at $37^{\circ} \mathrm{C}$ to $1 \mu \mathrm{mol} / \mathrm{l}$ ionomycin, a substance that rapidly activates cNOS via an increase of cytosolic $\mathrm{Ca}^{2+}(46) ;(\mathrm{v})$ the ability of insulin to increase NO synthesis, by measuring NO production as L- $\left[{ }^{3} \mathrm{H}\right]$-citrulline synthesis from $\mathrm{L}-\left[{ }^{3} \mathrm{H}\right]-$ arginine in cells incubated for $5 \mathrm{~min}$ at $37^{\circ} \mathrm{C}$ with $2 \mathrm{nmol} / \mathrm{l}$ insulin; (vi) the ability of insulin to increase both cGMP and cAMP via NO through the PI 3-kinase pathway of insulin signalling by measuring these cyclic nucleotides in cells incubated for $30 \mathrm{~min}$ at $37^{\circ} \mathrm{C}$ with human recombinant insulin at a concentration of $2 \mathrm{nmol} / \mathrm{l}$ both with and without a 20-min preincubation with the NOS inhibitor $\mathrm{N}^{\mathrm{G}}$-monomethyl-L-arginine (l-NMMA) at final concentration of $1 \mathrm{mmol} / \mathrm{l}$ and with the PI 3-kinase inhibitors wortmannin at final concentrations of 1 and $2 \mu \mathrm{mol} / \mathrm{l}$ and LY 294002 at a final concentration of $100 \mu \mathrm{mol} / \mathrm{l}$; (vii) the dose-dependence of the effect of insulin on cGMP and cAMP by cell incubation for $30 \mathrm{~min}$ at $37^{\circ} \mathrm{C}$ with human recombinant insulin at concentrations of $0,0.125,0.25,0.5,1$ and $2 \mathrm{nmol} / \mathrm{l}$; (viii) the time-dependence of the effect of insulin on cyclic nucleotide levels in the interval between $30 \mathrm{~s}$ and $360 \mathrm{~min}$; (ix) the influence of phosphodiesterase inhibition on the effects of insulin on cyclic nucleotides by carrying out experiments with a 20-min preincubation with theophylline $(500 \mu \mathrm{mol} / \mathrm{l})$ or 3-isobutyl-1methylxanthine (IBMX) $(500 \mu \mathrm{mol} / \mathrm{l})$; (x) the ability of insulin to interplay with the effects of guanylate cyclase activators by incubating the cells for $30 \mathrm{~min}$ with both insulin and SNP at 40 and $100 \mu \mathrm{mol} / \mathrm{l}$ and with both insulin and GTN at 40 and $100 \mu \mathrm{mol} / \mathrm{l}$; (xi) the ability of insulin to interplay with the effects of adenylate cyclase activators by incubating the cells for $30 \mathrm{~min}$ with both insulin and the stable prostacyclin analogue Iloprost $(500 \mathrm{pg} / \mathrm{ml})$ or forskolin $(2 \mu \mathrm{mol} / \mathrm{l})$.

\section{Chemicals}

Human recombinant insulin was obtained from Lilly Humulin R (Lilly France S.A., St Cloud, Paris, France); L-NMMA, type IA collagenase, L-arginine, forskolin, SNP, theophylline, IBMX, wortmannin and LY 294002 hydrochloride were obtained from Sigma (St Louis, MO, USA); GTN was obtained from Astra Farmaceutici S.p.A. (Milan, Italy); Iloprost, a stable prostacyclin analogue, was a gift from Schering S.p.A. (Milan, Italy); ionomycin was obtained from Boehringer Mannheim (Mannheim, Germany); L- $[2,3,4,5-3 \mathrm{H}]-$ arginine monohydrochloride $\left(2.3 \times 10^{12} \mathrm{~Bq} / \mathrm{nmol}\right.$; $62 \mathrm{Ci} / \mathrm{mmol}$ ) was from Amersham International (Amersham Pharmacia, Amersham, Bucks, UK); forskolin and wortmannin were dissolved in dimethylsulfoxide in a final concentration that did not exceed $0.25 \%(35 \mu \mathrm{mol} / \mathrm{l})$. In each experimental condition, each sample received the same amount of solvent.

\section{Cell isolation and culture}

Tissue samples of corpus cavernosum were obtained during the surgical procedure of corporoplasty. Penile specimens were surgically debrided and washed in physiological saline to remove blood. Samples were cut into fragments of about $1 \mathrm{~mm}^{2}$ by a sterile lancet and incubated for $2 \mathrm{~h}$ in a Petri dish in the presence of Hank's balanced salt solution (HSS) containing type IA collagenase $(2000 \mathrm{IU} / \mathrm{ml})$. After repeated washes with HSS, fragments were cultured under a coverslip in the presence of minimal essential medium (MEM) supplemented with 10\% fetal calf serum (FCS), $100 \mathrm{U} / \mathrm{ml}$ penicillin, $100 \mu \mathrm{g} / \mathrm{ml}$ streptomycin, $10 \mathrm{mmol} / \mathrm{l}$ glutamine and antibiotics, and buffered with $10 \mathrm{mmol} / \mathrm{l} \mathrm{N}$-Tris (hydroxymethyl) methyl-2-aminoethane-sulfonic acid and $10 \mathrm{mmol} / \mathrm{l}$ Hepes. Incubation was carried out at $37^{\circ} \mathrm{C}$ in a humidified incubator with an atmosphere of $5 \% \mathrm{O}_{2}: 95 \% \mathrm{CO}_{2}$ for 2 weeks and medium was replaced with fresh medium every 4 days. After 14 days, microscopic inspection allowed the observation of cell outgrowth and the coverslip was then removed with sterile forceps and incubated in another Petri dish. After a further 2 weeks, cells were detached by trypsinization ( $2.5 \mathrm{~g}$ porcine trypsin, $1 \mathrm{~g}$ EDTA, $100 \mathrm{ml}$ physiological saline), centrifugally washed and plated in other dishes. Cultures were morphologically homogeneous; neither a cobblestone morphology nor flattened, spread-out shapes were observed. The transfer procedure was repeated for subsequent passages and cells were cultured following standardized procedures in medium containing $10 \%$ FCS. The large majority of experiments were carried out for four to five passages. Human umbilical vein endothelial cells (HUVEC) were a generous gift from Professor Federico Bussolino, Institute for Cancer Research and Treatment, Candiolo-Turin, Italy.

\section{Immunofluorescence staining, fluorescence- activated cell sorting (FACS) separation and Western immunoblotting for cell characterization}

CSMC were cultured on glass coverslips until 70\% confluence, washed twice with phosphate-buffered saline (PBS) and fixed in freshly prepared $3.7 \%$ formaldehyde solution for $10 \mathrm{~min}$ at room temperature. Aspecific binding was blocked by treating cells with $1 \%$ serum bovine albumin (BSA) in PBS for 15 min. Cells were then incubated in PBS with $1 \%$ BSA containing primary antibody at $37^{\circ} \mathrm{C}$ for $60 \mathrm{~min}$, washed three times for $10 \mathrm{~min}$ each in PBS and then incubated with fluorescein isothiocyanate (FITC)-conjugated anti-mouse secondary antibody diluted 1:40 in PBS for $60 \mathrm{~min}$ at room temperature. The primary antibodies employed were monoclonal anti-smooth muscle actin and anti-desmin (Sigma-Aldrich, St Louis, MO, USA; dilution 1:30) and monoclonal anti-vimentin 
(BioMakoz, Rehovot, Israel; dilution 1:30). After washing in PBS three times for 10 min each, the coverslips were mounted in mounting medium on a microscope slide and viewed with a fluorescence LSM Zeiss confocal microscope. As a negative control, fixed cells treated only with FITC-conjugated anti-mouse secondary antibody were used. To exclude the presence of endothelial cells in the preparation, fixed cells were immunostained with an antiserum against the endothelial marker, von Willebrand Factor (clone F8/86; Dako, Carpinteria, CA, USA).

To detect the content of vascular smooth musclespecific $\alpha$-actin $(\alpha-S M A), 20 \mu \mathrm{g}$ total protein extract was separated by SDS-PAGE and electrotransferred to nitrocellulose membrane. The blot was first incubated with a monoclonal antibody against $\alpha$-SMA from Sigma Chemical Co. (1:1000 dilution), then with an anti-mouse horseradish peroxidase-linked second antibody. The blot was then detected with an EXL-plus kit (Amersham Life Sciences).

The purity of CSMC culture was evaluated by flow cytometry. The cells were detached with trypsin, washed in PBS supplemented with $0.2 \%$ BSA and 0.1 $\mathrm{NaN}_{3}$ and permeabilized with $0.05 \%$ saponin for $5 \mathrm{~min}$ at $4^{\circ} \mathrm{C}$. After two further washings, the cell samples were incubated $\left(30 \mathrm{~min}, 4^{\circ} \mathrm{C}\right)$ with the following monoclonal antibodies: anti-human $\alpha$-smooth muscle actin (clone 1 A4; Sigma), anti-human CD31 (Serotec, Oxford, Oxon, UK) and anti-human von Willebrand Factor (clone F8/86; Dako, Carpinteria, CA, USA). After two further washings, the cells were incubated $\left(30 \mathrm{~min}, 4^{\circ} \mathrm{C}\right)$ with FITC-conjugated antibody goat anti-mouse immunoglobulins (Dako). Antigen expressions were analyzed with a FACS scan flow cytometer (Beckton Dickinson, Milan, Italy). Each analysis represents the results from 10000 events. As negative controls, we used cells exposed only to the second antibody. HUVEC were used as positive controls for CD31 and von Willebrand Factor.

\section{Cell proliferation assay}

CSMC at initial passages were made quiescent by serum starvation and cultured in MEM/BSA. After $48 \mathrm{~h}$ quiescence, CSMC were detached by trypsinization and plated in $35 \mathrm{~mm}$ culture dishes at $1 \times 10^{4} \mathrm{cells} / \mathrm{ml}$ in $2 \mathrm{ml}$ fresh MEM containing different concentrations of FCS $(0,2,5,10$ and 20\%). CSMC were trypsinized at intervals and counted in a haemocytometric chamber. Viability was evaluated by the trypan blue exclusion technique.

Doubling time, expressed in hours, was calculated following the formula: $\left(\mathrm{t}_{2}-\mathrm{t}_{1}\right) \times \log 2 / \log \mathrm{Nt}_{2} / \mathrm{Nt}_{1}$ where $t_{2}-t_{1}$ was the time-interval expressed in hours between the cell count, $\mathrm{Nt}_{1}$ the cell number at time $\mathrm{t}_{1}$ and $\mathrm{Nt}_{2}$ the cell number at time $\mathrm{t}_{2}$.

Some experiments were carried out using the same procedure by exposing cultured cells to $2 \% \mathrm{FCS}$ in the presence of different concentrations of insulin (0.6$60 \mathrm{nmol} / \mathrm{l})$.

\section{Evaluation of mRNA for cNOS}

Total RNA was isolated from cultured CSMC and from HUVECs by the acid guanidinium-isothiocyanatephenol method (47). Total RNA $(5 \mu \mathrm{g})$ was reverse transcribed by first strand cDNA synthesis kit (Amersham Pharmacia Biotech, Little Chalfont, Bucks, UK) with an HPLC-purified cNOS specific primer 5'-TGTTGGTGTCTGAGCCGGG-3' (Amersham Pharmacia Biotech) designed on exon 26 of the published human endothelial NOS sequence (48). An aliquot of this cDNA solution was amplified in a total volume of $50 \mu \mathrm{l}$ with $30 \mathrm{mmol} / \mathrm{l}$ Tris-HCl buffer ( $\mathrm{pH} 8.3$ ), $2 \mathrm{mmol} / \mathrm{l} \mathrm{MgCl}_{2}$, 2.5 U AmpliTaq Gold DNA polymerase (Perkin Elmer Biosystems, Foster City, CA, USA) and two specific primers $(0.15 \mu \mathrm{mol} / \mathrm{l}$ each $)$ in a Perkin Elmer Gene Amp PCR System 2400. The sense (5'-GGGCCCAGAGCTACGCACAGC- $\left.3^{\prime}\right)$ and the antisense (5'-GTGCCCAGGGCCCCTGC- $\left.3^{\prime}\right)$ oligonucleotides, designed respectively on exon 12 and 16 of the published human endothelial NOS sequence (48), amplified a $345 \mathrm{bp}$ fragment of the cDNA.

The single PCR product obtained was electrophorized through a $1 \%$ agarose gel, transferred onto a Nylon Membrane (Schleicher and Schuell, Keene, NH, USA) and fixed by UV radiation. The blot was then hybridized with a cDNA probe specific for human endothelial NOS (Alexis Corp., Lausen, Switzerland) labelled by $\left[\alpha-{ }^{32}\right.$ P]dCTP Random Primer Labelling Kit (Amersham Pharmacia Biotech). The membrane was exposed for 2 days to Kodak Omat AR films (Kodak Co., Rochester, $\mathrm{NY}$, USA) at $-80^{\circ} \mathrm{C}$ with an intensifying screen (49).

\section{Immunofluorescence evidence of cNOS protein}

The presence of cNOS protein was evaluated as previously described by immunostaining fixed cells with a monoclonal anti-cNOS antibody (Transduction Laboratories, Lexington, KY, USA; dilution 1:50).

To show the simultaneous presence of cNOS protein and $\alpha$-SMA, we carried out double immunostaining experiments using the following antibodies: for $\alpha$-SMA, a rabbit antibody from Zymed Laboratories (San Francisco, CA, USA), and a tetramethyl-rhodamine isothiocyanate (TRITC)-goat anti-rabbit IgG-conjugated (Zymed Laboratories) secondary antibody; for cNOS the previously described monoclonal antibody and a FITC-conjugated antibody, goat anti-mouse immunoglobulins (Dako). The procedure was the same as that previously described and the cells were examined with a confocal microscope using FITC and TRITC filters simultaneously with a programme for co-localization assay. 


\section{Evaluation of NOS activity}

Since NO synthesis is catalyzed by NOS, which induces the conversion of L-arginine to L-citrulline and NO with a 1:1 stoichiometry $(46,50)$, the presence of NOS activity in cultured CSMC was checked as L- $\left[{ }^{3} \mathrm{H}\right]$-citrulline production from $\mathrm{L}-\left[{ }^{3} \mathrm{H}\right]$-arginine.

Briefly, cultured CSMC in $35 \mathrm{~mm}$ dishes were washed once with Hepes buffer $(145 \mathrm{mmol} / \mathrm{l} \mathrm{NaCl}, 5 \mathrm{mmol} / \mathrm{l}$ $\mathrm{KCl}, 1 \mathrm{mmol} / \mathrm{l} \mathrm{MgSO}_{4}, 10 \mathrm{mmol} / \mathrm{l}$ Hepes sodium salt, $10 \mathrm{mmol} / \mathrm{l}$ glucose and $1 \mathrm{mmol} / \mathrm{l} \mathrm{CaCl}_{2}, \mathrm{pH} 7.4$ ) and incubated in $1 \mathrm{ml}$ of the same buffer at $37^{\circ} \mathrm{C}$ for $20 \mathrm{~min}$. We added $\mathrm{L}-\left[{ }^{3} \mathrm{H}\right]$-arginine $\left(185 \times 10^{3} \mathrm{~Bq}\right.$; $5 \mu \mathrm{Ci}$ ) corresponding to a final concentration of $0.8 \mathrm{nmol} / \mathrm{l}$ to each dish and after $1 \mathrm{~min}$ cells were stimulated with $1 \mu \mathrm{mol} / \mathrm{l}$ ionomycin (to assess the calcium dependence of NOS activation) or $2 \mathrm{nmol} / \mathrm{l}$ insulin (to assess its ability to activate cNOS). After a 5-min incubation at $37^{\circ} \mathrm{C}$, the reaction was stopped by washing the dishes with $2 \mathrm{ml}$ cold PBS containing $5 \mathrm{mmol} / \mathrm{l}$ L-arginine and $4 \mathrm{mmol} / \mathrm{l}$ EDTA. Ethanol $(0.5 \mathrm{ml}, 96 \%)$ was then added and, after evaporation, $2 \mathrm{ml}$ $20 \mathrm{mmol} / \mathrm{l}$ Hepes-Na (pH 6) was added. The supernatant was collected, applied to $2 \mathrm{ml}$ columns of Dowex AG50WX-8 (Na ${ }^{+}$form) and eluted with $4 \mathrm{ml}$ distilled water. The radioactivity corresponding to $\mathrm{L}-\left[{ }^{3} \mathrm{H}\right]$-citrulline content in $6 \mathrm{ml}$ eluate was measured with liquid scintillation counting. The blank was prepared by incubating cells in $1 \mathrm{mmol} / \mathrm{l}$ cold L-arginine to remove the small percentage of $\mathrm{L}-\left[{ }^{3} \mathrm{H}\right]$-citrulline contaminating the $\mathrm{L}-\left[{ }^{3} \mathrm{H}\right]$-arginine preparation. We calculated that $\mathrm{L}-\left[{ }^{3} \mathrm{H}\right]$-citrulline present in the $\mathrm{L}-\left[{ }^{3} \mathrm{H}\right]-$ arginine preparation did not exceed 3\% of radioactivity.

\section{Cyclic nucleotide determination}

For the experiments investigating cyclic nucleotide determination, cells were cultured into 6 -well plates with medium containing $10 \%$ FCS until $70 \%$ confluence was achieved; the medium was then removed and replaced overnight with medium containing $1 \%$ FCS before exposure of the cells to the different substances as described in the section on study design. At the end of the different incubation periods, medium was removed from each well and $300 \mu \mathrm{l}$ absolute ethanol was added to permeabilize the cells. A complete evaporation of ethanol was obtained under shaking. Cyclic nucleotides were then dissolved in $300 \mu \mathrm{l}$ acetate buffer and kept at $-70{ }^{\circ} \mathrm{C}$ until the assays. cAMP and cGMP were measured by radioimmunoassay kits (Diagnostic Products Corporation Inc., Cambridge, MA, USA and Immuno Biological Laboratories, Hamburg, Germany respectively).

For the cGMP assay, the sensitivity was $0.05 \mathrm{pmol} / \mathrm{ml}$, the specificity was $100 \%$ for cGMP, $0.0004 \%$ for cAMP, $0.0001 \%$ for GMP, GDP, ATP and GTP and the intra-assay coefficient of variation was $4.4 \%$. For the cAMP assay, the sensitivity was less than $0.1 \mathrm{pmol} / \mathrm{ml}$, cross-reactivity with the other nucleotides was $100 \%$ for cAMP, $<0.1 \%$ for cGMP, $<0.001 \%$ for AMP, GDP, ATP, GTP and the intraassay coefficient of variation was $4.8 \%$.

\section{Statistical analysis}

Data are expressed as means \pm s.E.M. Six to twelve experiments were carried out for each experimental series. Statistical analysis was performed by means of analysis of variance (ANOVA) to determine the statistical significance of dose-response effects and by the unpaired Student's $t$-test when only two values were compared.

\section{Results}

\section{CSMC characterization and proliferation}

Human CSMC grew in culture as a homogeneous population of spindle-shaped cells with centrally located nuclei. The cells were positive for $\alpha$-SMA (granular pattern) (Fig. 1B) and desmin (data not shown). Figure 1C shows the immunofluorescence for vimentin, which was only used to indicate cytoskeleton morphology since it is not specific for vascular smooth muscle cells. Cells were negative for the endothelial marker von Willebrand Factor.

Immunoblotting showed the presence of vascular smooth muscle-specific $\alpha$-actin as a single band of $43 \mathrm{kDa}$.

The purity of cultured CSMC has been demonstrated by FACS positivity for $\alpha$-SMA (97\%) and negativity for the endothelial markers von Willebrand Factor and CD31. HUVEC presented the expected positivity for the endothelial markers.

Proliferation curves in the presence of different concentrations of FCS showed that the rate of cell proliferation increased in the presence of increasing FCS concentrations $(0,2,5,10 \%)$ up to $10 \%$, no further effect being elicited by FCS at $20 \%$.

As shown in Table 1, doubling times decreased in the presence of increasing FCS concentrations. Insulin concentrations ranging between 6 and $60 \mathrm{nmol} / \mathrm{l}$ increased the proliferation rate induced by low FCS levels (2\%) as shown in Fig. 2.

Table 1 Doubling time in hours (see text for formula) of CSMC in the presence of different concentrations of FCS.

\begin{tabular}{lcc}
\hline FCS (\%) & Day 4 & Day 10 \\
\hline 2 & 42.5 & 70.1 \\
5 & 34.1 & 58.7 \\
10 & 29.1 & 54.7 \\
20 & 29.4 & 54.8 \\
\hline
\end{tabular}



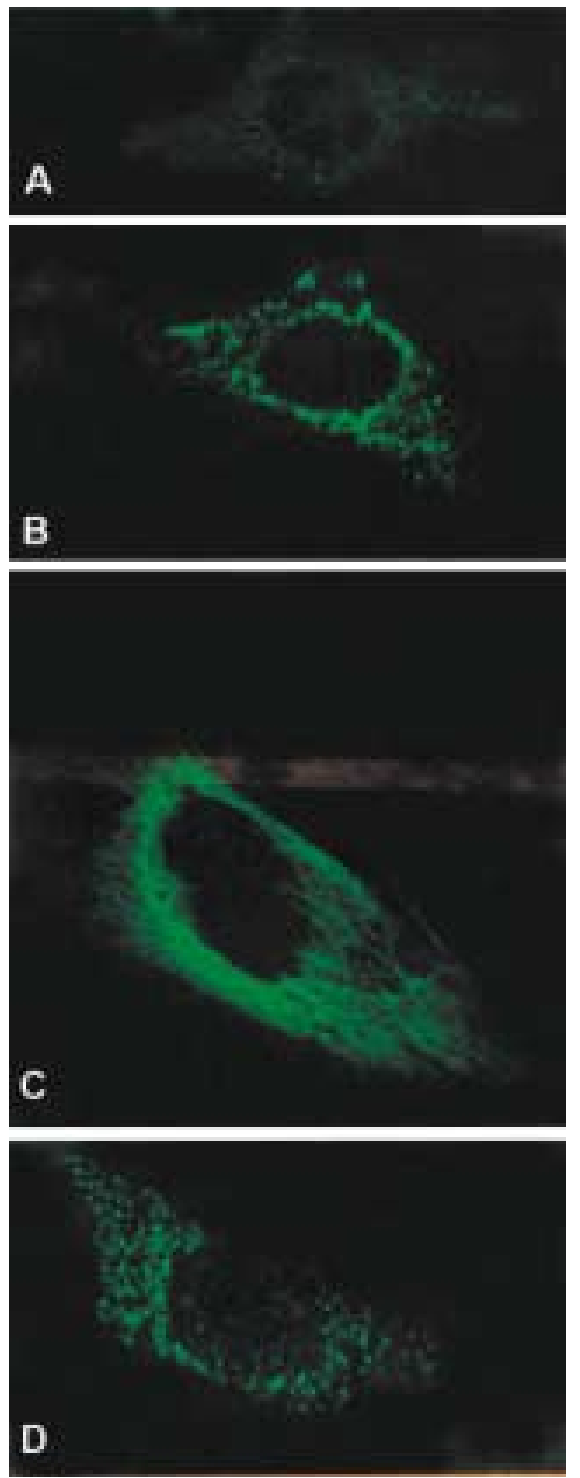

Figure 1 Immunofluorescence pattern for CSMC. (A) Control, (B) immunostaining with monoclonal antibody anti- $\alpha \mathrm{SMA}$, (C) immunostaining with monoclonal antibody anti-vimentin and (D) immunostaining with monoclonal antibody anti-cNOS (immunofluorescence pictures were obtained using confocal microscopy).

\section{Expression of mRNA for cNOS}

The expression of cNOS mRNA in CSMC was shown by RT-PCR. To confirm that the $345 \mathrm{bp}$ PCR product amplified from the cDNA reverse transcribed from total RNA using primers specific for cNOS belongs to cNOS mRNA, it was blotted and hybridized with a probe specific for the constitutive isoform of NOS (Fig. 3). mRNA expression for cNOS in HUVECs is also shown as a positive control.

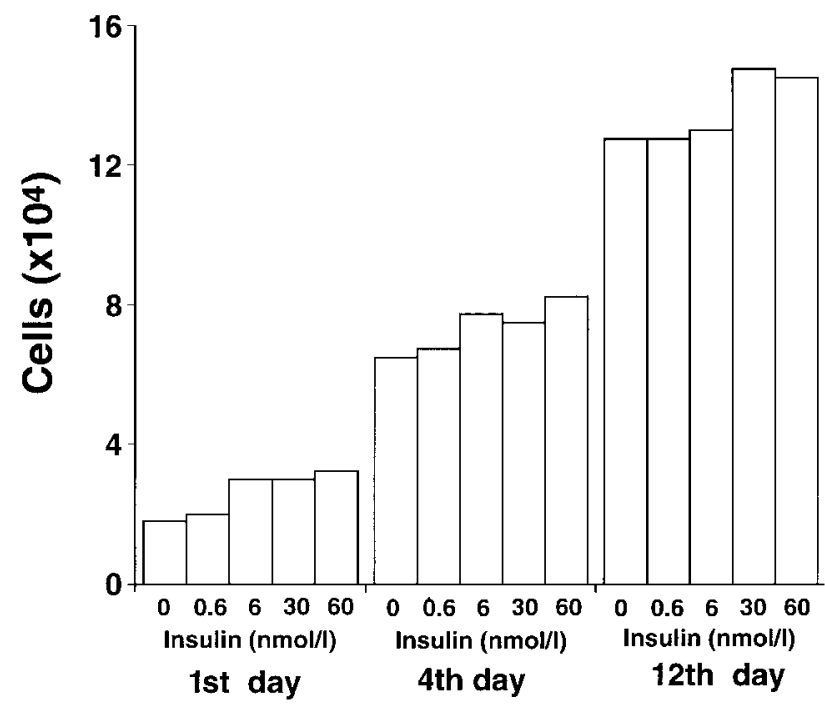

Figure 2 Effects of insulin on the proliferation of CSMC elicited by $2 \%$ FCS in the absence or the presence of different insulin concentrations $(0.6-60 \mathrm{nmol} / \mathrm{l})$.

\section{Evidence of cNOS protein}

Figure 1D shows that CSMC exhibited a clearly positive immunostaining with monoclonal anti-human cNOS antibody.

Figure 4 shows the simultaneous positivity for both $\alpha$-SMA and cNOS in a representative cell.

\section{Presence of a $\mathrm{Ca}^{2+}$-dependent NOS activity}

Ionomycin rapidly increased $\mathrm{L}-\left[{ }^{3} \mathrm{H}\right]$-citrulline production from $\mathrm{L}-\left[{ }^{3} \mathrm{H}\right]$ - arginine in $\operatorname{CSMC}(P=0.011)$ as shown in Fig. 5. Citrulline synthesis is a reliable marker of NO formation. These results indicate the presence of a $\mathrm{Ca}^{2+}$-dependent NOS activity in these cells.

\section{Evidence that insulin increases NO synthesis}

In CSMC, insulin rapidly increased NO synthesis, measured as $\mathrm{L}-\left[{ }^{3} \mathrm{H}\right]$-citrulline production from $\mathrm{L}-\left[{ }^{3} \mathrm{H}\right]-$ arginine $(P=0.041)$, as shown in Fig. 6 .

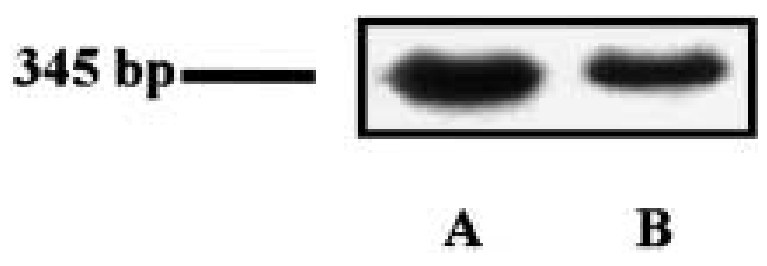

Figure 3 The $345 \mathrm{bp}$ fragment obtained by RT-PCR and hybridized with specific human cNOS probe in both (A) HUVEC and (B) CSMC. 


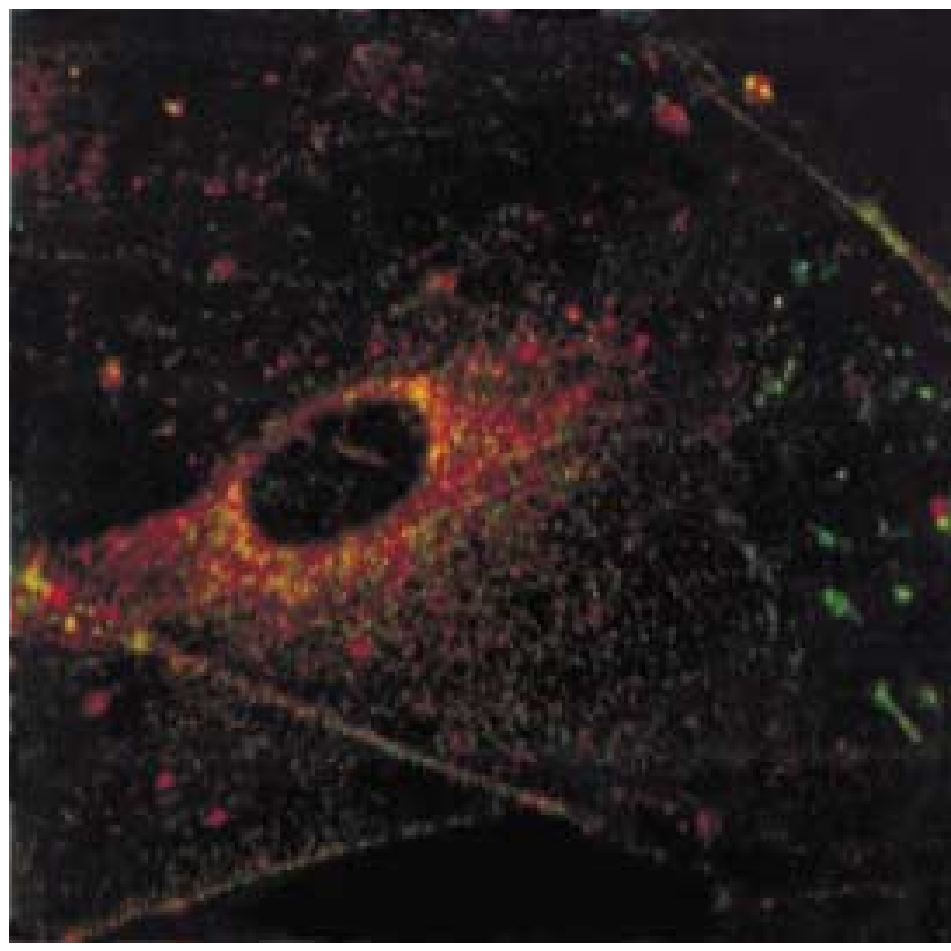

Figure 4 Double immunostaining of CSMC for $\alpha$-SMA (primary antibody: rabbit anti- $\alpha$-SMA; secondary antibody: TRITC-conjugated goat anti-rabbit $\lg G$ ) and cNOS (primary antibody: monoclonal anti-cNOS; secondary antibody: FITC-conjugated goat anti-mouse Igs). The positivity for cNOS is green, for $\alpha$-SMA it is red and for both it is orange-yellow.

\section{Evidence that insulin increases cell concentrations of both cGMP and cAMP via NO production involving the PI 3-kinase pathway of insulin signalling}

Figure 7 shows the effects of insulin on intracellular levels of both cyclic nucleotides. Insulin $(2 \mathrm{nmol} / \mathrm{l})$ induced an increase of cGMP after $30 \mathrm{~min}$ of incubation (Student's $t$-test: $P=0.0001$ for both cGMP and cAMP). Preincubation with L-NMMA and wortmannin $(2 \mu \mathrm{mol} / \mathrm{l})$ completely blunted the effects of insulin on

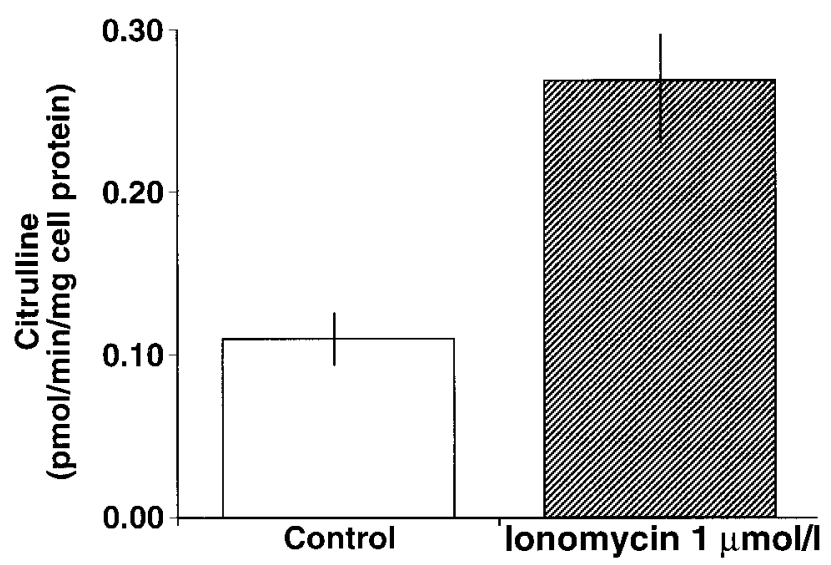

Figure 5 Influence of the calcium ionophore ionomycin $(1 \mu \mathrm{mol} / \mathrm{l})$ on NO synthesis in CSMC, shown as $L-\left[{ }^{3} \mathrm{H}\right]$-citrulline production from $\mathrm{L}-\left[{ }^{3} \mathrm{H}\right]$-arginine $(P=0.011)(n=12)$ both cGMP and cAMP (Fig. 7). A significant reduction in the action of insulin was observed also with $1 \mu \mathrm{mol} / \mathrm{l}$ wortmannin $(P=0.0001 \mathrm{vs}$ insulin alone). The involvement of PI 3-kinase in the action of insulin on both cyclic nucleotides has been further confirmed by the complete inhibition exerted by LY 294002, another PI 3-kinase inhibitor, when the cGMP values (pmol/10 $10^{6}$ cells) in the presence of LY 294002 (100 $\mu \mathrm{mol} / \mathrm{l})$ were $3.6 \pm 0.21$ without and $2.88 \pm 0.32$ with $2 \mathrm{nmol} / \mathrm{l}$ insulin (not significant).

\section{Dose-dependent effect of insulin on cell concentrations of both cGMP and cAMP}

The dose-dependent effects of insulin (30-min exposure) on cGMP and cAMP are shown in Fig. 8. Dose-dependent effects were found for both cyclic nucleotides (ANOVA for repeated measures: $P=$ 0.0001 for both cGMP and cAMP). For cGMP, the effects of insulin were significant at the following concentrations: $0.25 \mathrm{nmol} / \mathrm{l}, \quad P=0.005 ; \quad 0.5, \quad 1$ and $2 \mathrm{nmol} / \mathrm{l}, P=0.0001$. For cAMP, the effects of insulin were significant at the following concentrations: 0.25 , $0.5,1$ and $2 \mathrm{nmol} / \mathrm{l}, P=0.0001$.

\section{Time-dependence of the effect of insulin on cell concentrations of both cGMP and cAMP}

Figure 9 shows the behaviour of cyclic nucleotide concentrations at different times $(0-360 \mathrm{~min})$ after exposure to insulin $(2 \mathrm{nmol} / \mathrm{l})$. For both cyclic nucleotides, 

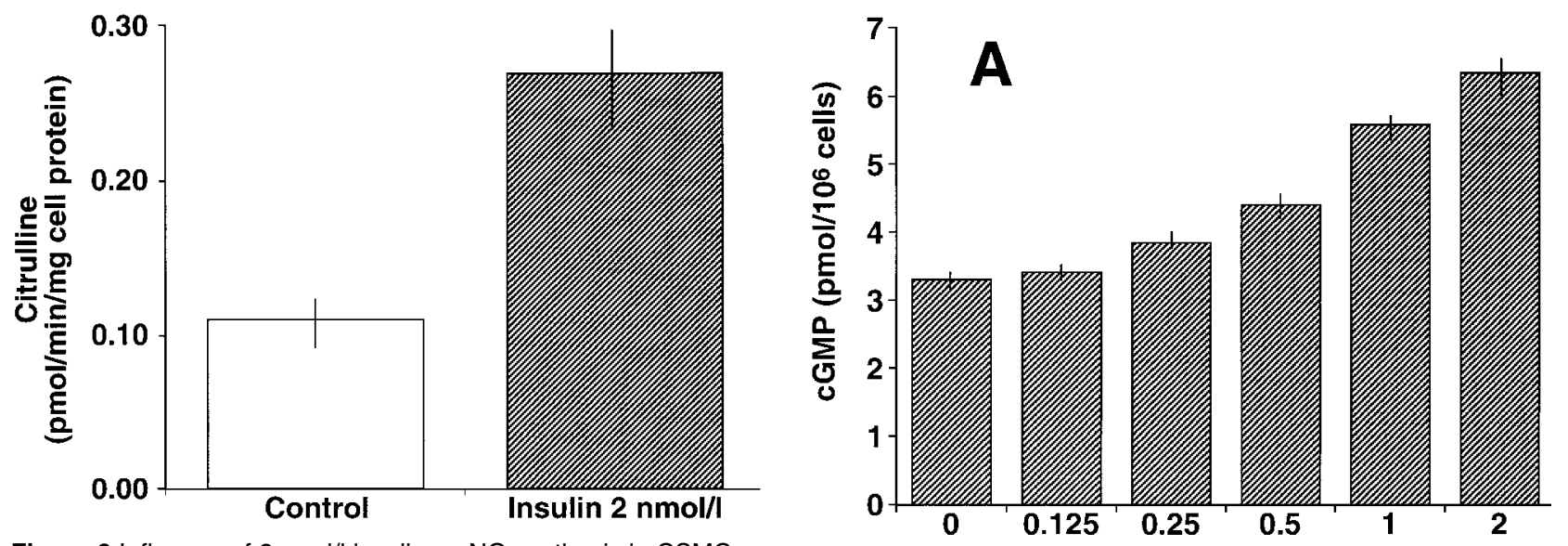

Figure 6 Influence of $2 \mathrm{nmol} / \mathrm{l}$ insulin on NO synthesis in CSMC, shown as $\mathrm{L}-\left[{ }^{3} \mathrm{H}\right]$-citrulline production from $\mathrm{L}-\left[{ }^{3} \mathrm{H}\right]$-arginine $(P=$ $0.041)(n=12)$

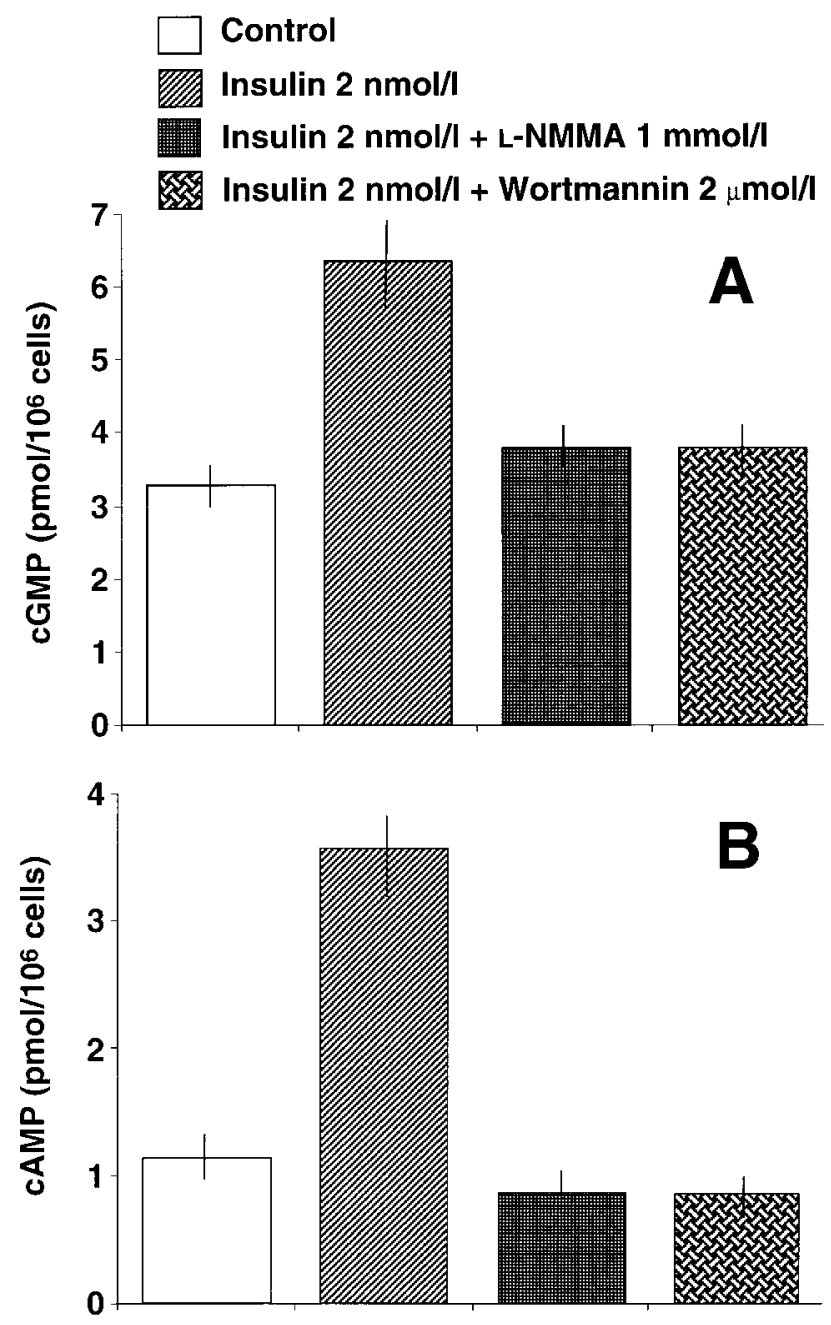

Figure 7 Influence of the NOS inhibitor L-NMMA ( $1 \mathrm{mmol} / \mathrm{l})$ and the PI 3-kinase inhibitor wortmannin $(2 \mu \mathrm{mol} / \mathrm{l})$ on the effects of insulin on (A) cGMP and (B) CAMP in CSMC $(n=6)$.

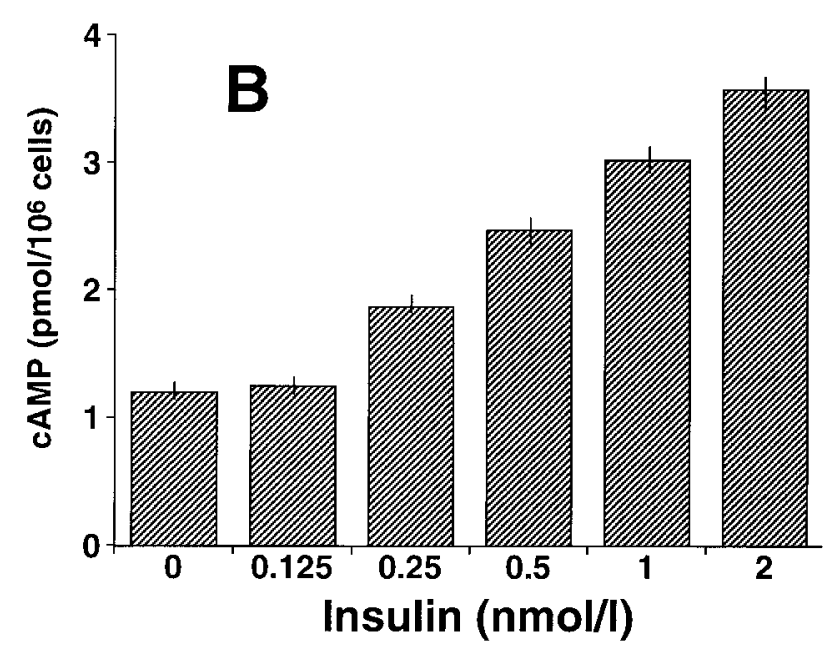

Figure 8 Dose-dependence of the effect of insulin on intracellular levels of (A) cGMP and (B) CAMP in CSMC. Levels of significance are described in the text $(n=6)$.

the insulin-induced increase was highly significant (ANOVA; $P=0.0001$ ) and a time-dependence of the response was clearly evident. In particular, (i) cGMP values were significantly higher than basal concentrations at $0.5,1,2,4,8,10,15,30,60,90$ and $120 \mathrm{~min}(P=0.0001$ at each control $)$, with a peak at $30 \mathrm{~min}$; the difference versus basal was no more significant starting from $180 \mathrm{~min}$, with a return to basal values at $240 \mathrm{~min}$ and (ii) cAMP values were higher than basal concentrations at $0.5(P=0.028), 1,2$, $4,8,10,15,30,60,90$ and $120 \mathrm{~min}(P=0.0001)$ and $180 \mathrm{~min}(P=0.004)$, with a peak at $60 \mathrm{~min}$; values returned to basal at $240 \mathrm{~min}$.

\section{Evidence that the action of insulin on cyclic nucleotides persists with phosphodiesterase inhibition}

The preincubation with the phosphodiesterase inhibitor theophylline $(500 \mu \mathrm{mol} / \mathrm{l})$ increased basal values of both cGMP and cAMP $(P=0.0001$ for both cyclic 

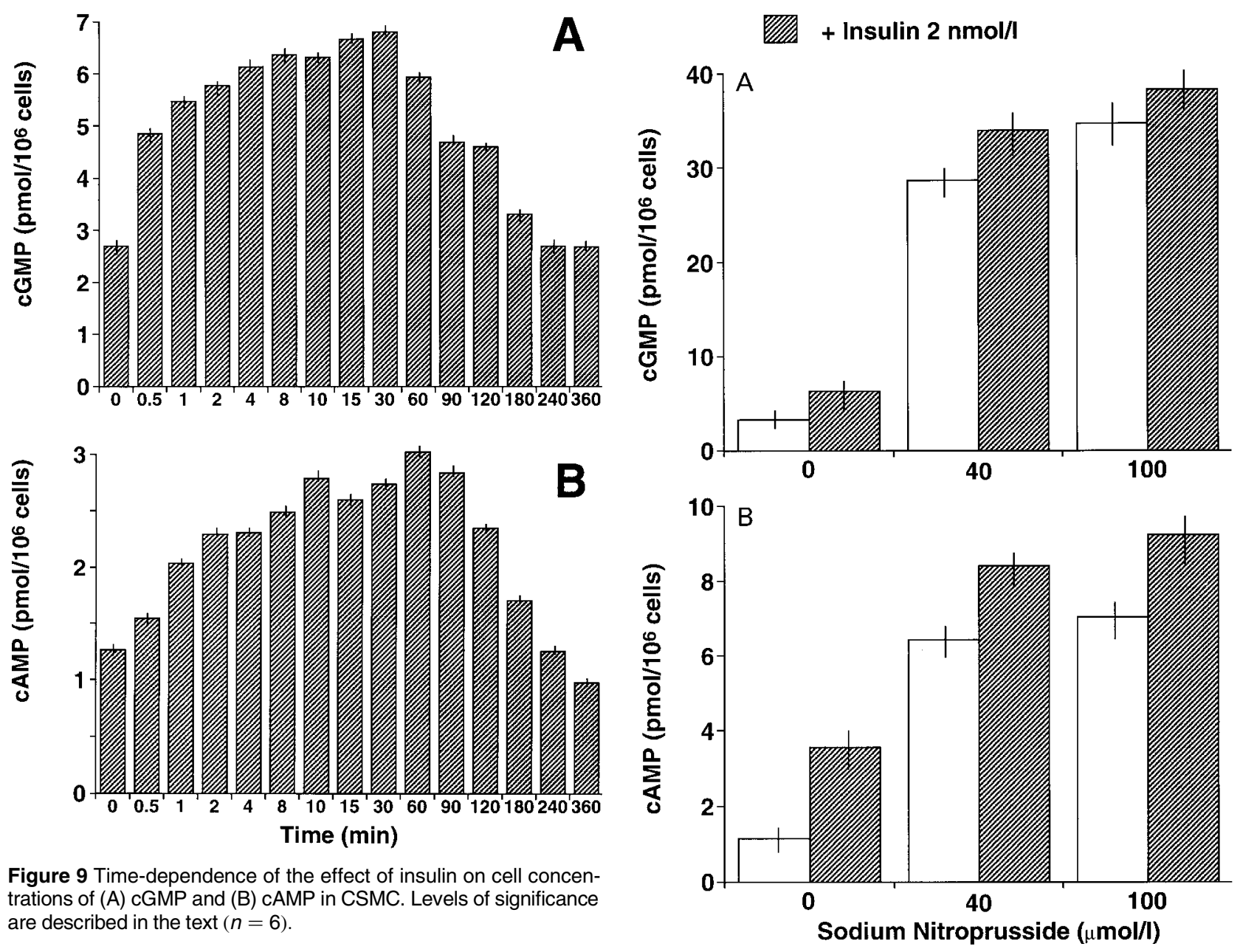

Figure 9 Time-dependence of the effect of insulin on cell concentrations of $(A)$ cGMP and (B) CAMP in CSMC. Levels of significance are described in the text $(n=6)$.

nucleotides); also in these experimental conditions, insulin further increased the concentrations of cGMP, from $14.19 \pm 1.39$ to $16.72 \pm 2.14 \mathrm{pmol} / 10^{6}$ cells $(P=$ $0.0001)$ and of cAMP, from $3.52 \pm 0.17$ to $8.72 \pm$ $0.40 \mathrm{pmol} / 10^{6}$ cells $(P=0.0001)$. The effects of insulin were also preserved in the presence of IBMX, another phosphodiesterase inhibitor: in particular, in the presence of $500 \mu \mathrm{mol} / \mathrm{l}$ IBMX, cGMP values (pmol/10 ${ }^{6}$ cells) were $11.51 \pm 0.32$ without and $14.68 \pm 0.66$ with $2 \mathrm{nmol} / \mathrm{l}$ insulin $(P=0.002)$.

\section{Evidence that the action of insulin on cyclic nucleotides persists in the presence of guanylate cyclase activation by NO donors}

Stimulation of guanylate cyclase by SNP caused a significant increase in both cGMP $(P=0.0001$ with both 40 and $100 \mu \mathrm{mol} / \mathrm{l})$ and cAMP $(P=0.0001$ with both 40 and $100 \mu \mathrm{mol} / \mathrm{l})$. When insulin was co-incubated with SNP, cGMP and cAMP values were further increased (for cGMP: $P=0.002$ and $P=$ 0.0001 with 40 and $100 \mu \mathrm{mol} / \mathrm{l}$ respectively; for cAMP $P=0.04$ with both 40 and $100 \mu \mathrm{mol} / \mathrm{l}$ )

Figure 10 Influence of 30-min incubation with insulin, SNP and insulin + SNP on (A) cGMP and (B) CAMP in CSMC. Levels of significance are described in the text $(n=6)$.

(Fig. 10). Similar results have been obtained with GTN (data not shown).

\section{Evidence that insulin action on $\mathrm{cAMP}$ persists in the presence of adenylate cyclase activation by receptor-mediated (Iloprost) or non- receptor-mediated (forskolin) mechanisms}

The stimulation of adenylate cyclase activity by Iloprost resulted in a significant increase in cAMP values $(P=$ $0.0001)$. When insulin was co-incubated with Iloprost, cAMP values were further increased $(P=0.0001)$ (Fig. 11). The stimulation of adenylate cyclase activity by forskolin resulted in a significant increase in cAMP values $(P=0.0001)$. When insulin was co-incubated with forskolin, cAMP values were further increased $(P=0.008)$ (Fig. 11). 


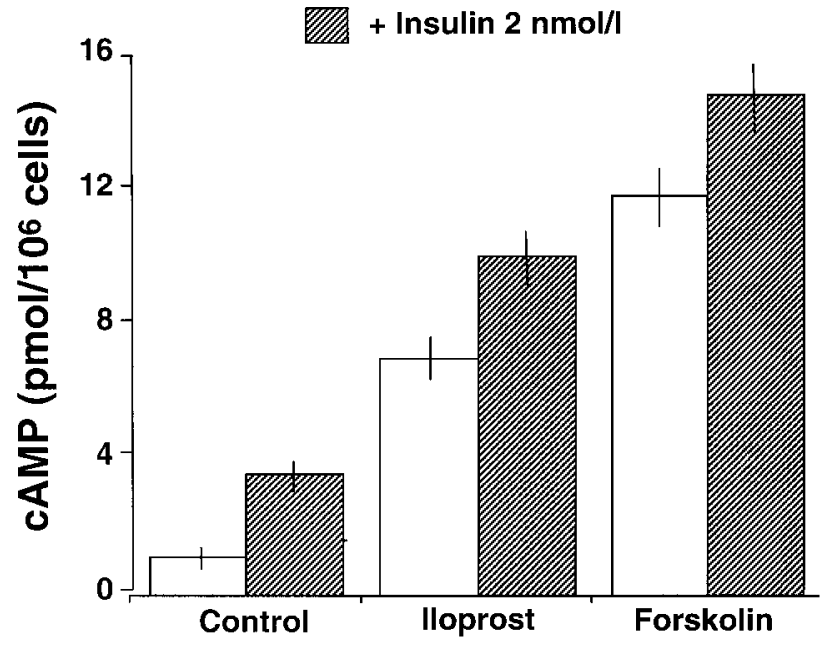

Figure 11 Influence of 30-min incubation with insulin, lloprost, insulin + lloprost, forskolin, and insulin+forskolin on cAMP in CSMC. Levels of significance are described in the text $(n=6)$.

\section{Discussion}

In this study, we have described experiments carried out on cultured CSMC. As far as we know, it is one of the few investigations concerning isolation, primary culture and characterization of this cell type and the first one showing the effect of insulin on their proliferation. Under our conditions, cells grew in culture as a homogeneous spindle-shaped population with centrally located nuclei. They exhibited the specific markers of vascular smooth muscle cells $\alpha$-actin (both in immunofluorescence, in Western immunoblotting and in the FACS scan) and desmin. Furthermore, they proliferated in a dose-dependent way according to the different FCS concentrations up to $10 \%$. In the presence of low FCS concentrations, insulin at very high, absolutely nonphysiological concentrations $(6-60 \mathrm{nmol} / \mathrm{l})$ slightly increased the proliferation rate.

The study clearly shows for the first time, via a molecular biology technique, that CSMC express an endothelial-type constitutive $\mathrm{Ca}^{2+}$-dependent NOS, adding a further element to the present debate on this relevant topic. It also demonstrated for the first time that cNOS in CSMC is a biologically active calciumdependent enzyme, able to produce detectable basal values of NO and to be further stimulated by a calcium ionophore. Our data, therefore, have shown that CSMC are not only targets of NO derived from endothelial cells or from nerve endings, but are also a source of NO potentially involved in the mechanism of erection, even if further studies are needed to evaluate the physiological role of NO constitutively produced by CSMC in human penile erection.

Furthermore, this study has shown that, in CSMC: (i) insulin activates cNOS; (ii) via NO, insulin increases cell concentrations of the vasodilating cyclic nucleotides cGMP and cAMP; (iii) the effects of insulin on the
NO-cGMP/cAMP cascade are mediated by the signalling pathway of PI 3-kinase, the same as the one by which insulin activates cNOS in endothelial cells (42), as the experiments with the PI 3-kinase inhibitor wortmannin clearly demonstrate; (iv) the effects of insulin on both cGMP and cAMP persist when the synthetic enzymes guanylate cyclase and adenylate cyclase are stimulated, and when the catabolic enzyme phosphodiesterases are inhibited by theophylline and IBMX, which inhibit all the phosphodiesterases, and therefore also phosphodiesterase $\mathrm{V}$ - which seems to be the main agent catalysing the breakdown of cGMP in corporal smooth muscle - without being specific for it.

Our study has, therefore, provided evidence that in the complex mechanism of penile erection insulin could play a role by increasing NO production in CSMC, with a consequent enhancement of both cGMP and cAMP and interplay with other physiologic mediators.

The involvement of NO in the insulin-induced increase, not only of cGMP but also of cAMP, in CSMC agrees with previous studies carried out in our laboratory both in platelets (43) and in vascular smooth muscle cells $(38,39)$; this study, on the other hand, has demonstrated that, also in CSMC, nitrates enhance not only cGMP but also cAMP, as previously described in human vascular smooth muscle cells (33) and in platelets $(34,35)$. The NO-mediated, insulininduced increase in cAMP is preserved in the presence of phosphodiesterase inhibition; thus, the inhibition of a cAMP phosphodiesterase by cGMP (36) is less likely to account for the cAMP increase than the ability of NO by itself to modify the guanylate cyclase properties inducing an adenylate-cyclase activity (37).

As far as the well-known vasodilating agents are concerned, we have shown in CSMC the expected responses to adenylate cyclase activation by the prostacyclin analogue Iloprost and forskolin. As far as forskolin is concerned, our data provide further evidence of its direct effects on CSMC that provide the rationale for its use in erectile dysfunction $(51,52)$. Furthermore, we have demonstrated that insulin enhances the effect of both Iloprost and forskolin on cAMP content. The interplay with forskolin demonstrates that the effect of insulin on cAMP is not specific for receptor-activating agents, but is extended to other substances acting independently of receptor-mediated mechanisms. We believe that insulin increases cAMP per se via NO, and therefore enhances the effects of all the substances able to increase cAMP synthesis with different mechanisms.

Furthermore, insulin increases both cGMP and cAMP in CSMC also in the presence of NO donors activating guanylate cyclase. This phenomenon is interesting, since both insulin and NO donors act via NO in guanylate cyclase stimulation. Our study, therefore, supports the conclusion that, when NO donors are employed, the insulin-induced increase of endogenous NO continues to exert biological effects on guanylate cyclase. 
In summary, this study has indicated a method to isolate, from human penile tissue, smooth muscle cells sensitive to different mediators and exhibiting a $\mathrm{Ca}^{2+}$-dependent NOS activity able to be stimulated by insulin in a few minutes. The present results are potentially relevant to better understanding the mechanisms involved in penile erection in man. Even though it is known that insulin induces an NO-mediated systemic vasodilation in vivo $(40,41)$, no investigation has, as yet, considered the effects of insulin on penile circulation. Our results, therefore, provide the first evidence that insulin, via an increase of both the vasodilating cyclic nucleotides in smooth muscle cells from human corpus cavernosum, directly influences mechanisms deeply involved in the vascular tone of the penis and interplays with classical haemodynamic mediators.

\section{References}

1 Schiavi RC, Stimmel BB, Mandeli J \& Rayfield EJ. Diabetes mellitus and male sexual function: a controlled study. Diabetologia 1993 $36745-751$.

2 Feldman HA, Goldstein I, Hatzichristou DG, Krane RJ \& McKinlay JB. Impotence and its medical and psychological correlates: results of the Massachusetts Male Aging Study. Journal of Urology $199415154-61$.

3 Fedele D, Coscelli C, Cucinotta D, Forti G, Santeusanio F, Viaggi S et al. Incidence of erectile dysfunction in Italian men with diabetes. Journal of Urology $2001 \mathbf{1 6 6} 1368-1371$.

4 Andersson KE \& Stief CG. Neurotransmission and the contraction and relaxation of penile erectile tissue. World Journal of Urology $19971514-20$.

5 Andersson KE \& Wagner G. Physiology of penile erection. Physiological Reviews $199575191-236$.

6 McKenna KE. Central control of penile erection. International Journal of Impotence Research 199810 (Suppl 1) S25-S34.

7 Schultheiss D \& Stief CG. Physiology and pathophysiology of erection: consequences for present medical therapy of erectile dysfunction. Andrologia 199931 (Suppl 1) 59-64.

8 Anderssson HE. Neurotransmitters: central and peripheral mechanisms. International Journal of Impotence Research $2000 \mathbf{1 2}$ S26-S33.

9 Ignarro LJ, Bush PA, Buga GM, Wood KS, Fukoto JM \& Raijfer J. Nitric oxide and cyclic GMP formation upon electrical field stimulation cause relaxation of corpus cavernosum smooth muscle. Biochemical and Biophysical Research Communications 1990170 843-850.

10 Kim N, Azadzoi KM, Goldstein I \& Saenz de Tajeda I. A nitric oxide-like factor mediates nonadrenergic-noncholinergic neurogenic relaxation of penile corpus cavernosum smooth muscle. Journal of Clinical Investigation 199188 112-118.

11 Burnett AL, Lowenstein CJ, Bredt DS, Chang TSK \& Snyder SH. Nitric oxide: a physiological mediator of penile erection. Science $1992257401-403$.

12 Raifer J, Aronson WJ, Bush PA, Dorey FJ \& Ignarro LJ. Nitric oxide as a mediator of the corpus cavernosum in response to noncholinergic, nonadrenergic neurotransmission. New England Journal of Medicine $1992 \mathbf{3 2 6} 90-94$.

13 Ehmke H, Junemann KP, Mayer B \& Kummer W. Nitric oxide synthase and vasoactive intestinal polypeptide colocalization in neurons innervating the human penile circulation. International Journal of Impotence Research 19957 147-156.

14 Bush PA, Aronson WJ, Buga GM, Reifer J \& Ignarro LJ. Nitric oxide is a potent relaxant of human and rabbit corpus cavernosum. Journal of Urology 1992147 1650-1655.
15 Bush PA, Aronson WJ, Rajfer J \& Ignarro LJ. Comparison of nonadrenergic-noncholinergic and nitric oxide-mediated relaxation of corpus cavernosum. International Journal of Impotence Research $1992485-93$.

16 Knispel HH, Goessl C \& Beckmann R. Nitric oxide mediates relaxation in rabbit and human corpus cavernosum smooth muscle. Urological Research $199220253-257$.

17 Burnett AL. Role of nitric oxide in the physiology of erection. Biology of Reproduction $1995 \mathbf{5 2} 485-489$.

18 Burnett AL. Nitric oxide in the penis: physiology and pathology. Journal of Urology 1997157 320-324.

19 Simonsen U, Prieto D, Delgado JA, Hernandez M, Resel L, Saenz de Tejade IS et al. Nitric oxide is involved in the inhibitory neurotransmission and endothelium-dependent relaxations of human small penile arteries. Clinical Science 199792 269-275.

20 Christ GJ. The penis as a vascular organ: the importance of corporal smooth muscle tone in the control of erection. Urologic Clinics of North America 199522 727-745.

21 Lue TF \& Dahiya R. Molecular biology of erectile function and dysfunction. Molecular Urology 19971 55-64.

22 Porst $\mathrm{H}$. The rationale for prostaglandin E1 in erectile failure: a survey of worldwide experience. Journal of Urology $1996 \mathbf{1 5 5}$ $802-815$.

23 Taher A, Meyer M, Stief CG, Jonas U \& Forssmann WG. Cyclic nucleotide phosphodiesterase in human cavernous smooth muscle. World Journal of Urology $19771532-35$.

24 Saenz de Tejada I, Blanco R, Goldstein I, Azadzoi K, Des las Morenas A, Krane RJ et al. Cholinergic neurotransmission in human corpus cavernosum. I. Response of isolated tissue. American Journal of Physiology $1988 \mathbf{2 5 4} \mathrm{H} 459-\mathrm{H} 476$.

25 Rembold CM. Regulation of contraction and relaxation in arterial smooth muscle. Hypertension 199220 129-137.

26 Palmer LS, Valcic M, Melman A, Giraldi A, Wagner G \& Christ GJ. Characterization of cyclic AMP accumulation in cultured human corpus smooth muscle cells. Journal of Urology $1994 \mathbf{1 5 2}$ $1308-1314$.

27 Somlyo AP \& Somlyo AV. Signal transduction and regulation in smooth muscle. Nature 1994372 231-236.

28 Stief CG, Noack T \& Andersson KE. Signal transduction in cavernous smooth muscle. World Journal of Urolology 199715 $27-31$.

29 Krall JF, Fittinoff M \& Rajfer J. Characterization of cyclic nucleotide and inositol-1,4,5-triphosphate-sensitive calcium-exchange activity of smooth muscle cells cultured from the human corpora cavernosa. Biology of Reproduction 198839 913-922.

30 Maggi M, Filippi S, Ledda F, Magini A \& Forti G. Erectile dysfunction: from biochemical pharmacology to advances in medical therapy. European Journal of Endocrinology 2000143 143-154.

31 Walsh MP. Regulation of vascular smooth muscle. Canadian Journal of Physiology and Pharmacology 199472 919-936.

32 Abdel-Latif AA. Cross talk between cyclic nucleotides and polyphosphoinositide hydrolysis, protein kinases, and contraction in smooth muscle. Experimental Biology and Medicine 2001226 153-163.

33 Trovati M, Massucco P, Mattiello L, Costamagna C, Aldieri E, Cavalot F et al. Human vascular smooth muscle cells express a constitutive nitric oxide synthase that insulin rapidly activates, thus increasing guanosine $3^{\prime}: 5^{\prime}$-cyclic monophosphate and adenosine $3^{\prime}: 5^{\prime}$-cyclic monophosphate concentrations. Diabetologia $199942831-839$.

34 Anfossi G, Massucco P, Mularoni E, Cavalot F, Mattiello L \& Trovati M. Organic nitrates and compounds that increase intraplatelet cyclic guanosine monophosphate (cGMP) levels enhance the anti-aggregating effects of the stable prostacyclin analogue Iloprost. Prostaglandins, Leukotrienes and Essential Fatty Acids $199349839-845$.

35 Anfossi G, Massucco P, Mularoni E, Cavalot F, Mattiello L \& Trovati M. Effect of forskolin and organic nitrates on aggregation and intracellular cyclic nucleotide content in human platelets. General Pharmacology 199425 1093-1100. 
36 Maurice DH \& Haslam RJ. Molecular basis of the synergistic inhibition of platelet function by nitrovasodilators and activators of adenylate cyclase: inhibition of cyclic AMP breakdown by cyclic GMP. Molecular Pharmacology 199037 671-681.

37 Mittal KC \& Murad F. Formation of adenosine $3^{\prime}, 5^{\prime}$-monophosphate by preparations of guanylate cyclase from rat liver and other tissues. Journal of Biological Chemistry 1977252 31363140.

38 Trovati M, Massucco P, Mattiello L, Cavalot F, Mularoni E, Hahn A et al. Insulin increases cyclic nucleotide content in human vascular smooth muscle cells: a mechanism potentially involved in insulin-induced modulation of vascular tone. Diabetologia 1995 38 936-941.

39 Trovati M, Massucco P, Mattiello L, Cavalot F, Mularoni EM, Hahn AW et al. Studies on the influence of insulin on cyclic adenosine monophosphate in human vascular smooth muscle cells: dependence on cyclic guanosine monophosphate and modulation of catecholamine effects. Diabetologia 199639 1156-1164.

40 Steinberg HO, Brechtel G, Johnson A, Fineberg N \& Baron A. Insulin-mediated skeletal muscle vasodilation is nitric oxide dependent. A novel action of insulin to increase nitric oxide release. Journal of Clinical Investigation $1994941172-1179$.

41 Scherrer U, Randin D, Vollenwieder L \& Nicod P. Nitric oxide release accounts for insulin's vascular effects in humans. Journal of Clinical Investigation $1994942511-2515$.

42 Zeng G \& Quon MJ. Insulin-stimulated production of nitric oxide is inhibited by wortmannin. Direct measurement in vascular endothelial cells. Journal of Clinical Investigation 199698 894-898.

43 Trovati M, Anfossi G, Massucco P, Mattiello L, Costamagna C, Piretto $\mathrm{V}$ et al. Insulin stimulates nitric oxide synthesis in human platelets and, through nitric oxide, increases platelet concentrations of both guanosine- $3^{\prime}, 5^{\prime}$-cyclic monophosphate and adenosine- $3^{\prime}, 5^{\prime}$-cyclic monophosphate. Diabetes 199746742 749.

44 Bloch W, Klotz T, Sedleczek P, Zumbe J, Engelmann U \& Addicks K. Evidence for the involvement of endothelial nitric oxide synthase from smooth muscle cells in the erectile function of the corpus cavernosum. Urological Research 199826 129-135.

45 Stanarius A, Uckert S, Machtens SA, Stief CG, Wolf G \& Jonas U. Immunocytochemical distribution of nitric oxide synthase in the human corpus cavernosum: an electron microscopical study using the tyramide signal amplification technique. Urological Research 200129 168-172.

46 Ghigo D, Alessio P, Foco A, Bussolino F, Costamagna C, Heller R et al. Nitric oxide synthesis is impaired in glutathione-depleted human umbilical vein endothelial cells. American Journal of Physiology 1993265 C728-C732.

47 Chomczynski P \& Sacchi N. Single-step method of RNA isolation by acid guanidinium thiocyanate-phenol-chlorophorm extraction. Analytical Biochemistry 1987162 156-159.

48 Marsden PA, Schappert KT, Chen H-S, Flowers M, Lamas S, Sundell CL et al. Molecular cloning and characterization of human endothelial nitric oxide synthase. FEBS Letters 1992 307 287-293.

49 Maniatis T, Fritsch EF \& Sambrook J. Molecular Cloning: A Laboratory Manual. Cold Spring Harbor: Cold Spring Harbour Laboratory Press, 1982.

50 Palmer RMJ, Ferrige AG \& Moncada S. A novel citrulline-forming enzyme implicated in the formation of nitric oxide by vascular endothelial cells. Biochemical and Biophysical Research Communications $1989158348-352$.

51 Cahn D, Melman A, Valcic M \& Christ GJ. Forskolin: a promising new adjunct to intracavernous pharmacotherapy. Journal of Urology $19961551789-1794$.

52 Mulhall JP, Daller M, Traish AM, Gupta S, Park K, Salimpour P et al. Intracavernosal forskolin: role in management of vasculogenic impotence resistant to standard 3-agent pharmacotherapy. Journal of Urology $1997 \mathbf{1 5 8} 1752-1758$.

Received 14 March 2002

Accepted 8 July 2002 